\title{
Dynamics of Stomach Growth in the Human Fetal Period - a Postmortem Study
}

\author{
Dinámica de Crecimiento del Estómago en el Período Fetal Humano - un Estudio Post-Mortem \\ "Bohdan Gworys; "* Slawomir Jeka; ** Radoslaw Brukiewa \& **Marcin Rymko
}

GWORYS, B.; JEKA, S.; BRUKIEWA, R. \& RYMKO, M. Dynamics of stomach growth in the human fetal period - a postmortem study. Int. J. Morphol., 30(2):461-466, 2012.

SUMMARY: The aim of this work was to analyze the stomach growth rate, variability of proportion and shape during prenatal period, as well as evaluation of final features differentiation process distinctive for perinatal period. It seems interesting to compare stomach growth analyzed in situ on post-mortem fetuses with results obtained by other authors evaluating this process in sonographic examinations. Research was conducted on 225 post-mortem fetuses 12 th to 40 th week of fetal age. There were measurements of stomach total length, lengths of greater and lesser curvature and cardia and pylorus widths performed. We evaluated the thickness of stomach front wall and bottom and its total mass. Statistical analysis was performed using statistical program package Statistica 8 . Rate of post mortem examined stomach dimensions growth - estimated on the base of mean conditional values is characterized by diverse rhythm. Proportions variability during prenatal period results from disharmonic growth of its dimensions. There were no dysmorphic differences in process of fetal stomach growth and in dynamics of its proportions and shapes changes found. In fetal period marks clearly tendency to organ shape changes consistent with fetal age. Based on analysis performed - four stages of stomach growth in fetal period were distinguished: 1 . Intensive growth phase last till 22th fetal week. 2. Formation of final stomach shape between 20th and 26th gestational age. 3. Phase of stomach topography changes between 26th and 30th gestational age. 4. Phase of harmonic growth lasts from 30th week until childbirth.

KEY WORDS: Stomach; Fetal development.

\section{INTRODUCTION}

Gastrointestinal tract structure and development in fetal period is subject of study for anatomists, gynecologists and radiologists (Nagata et al., 1990; Macarulla-Sanz et al., 1996; Cetin et al., 2006; Koyuncu et al., 2009). For obstetricians, neonatologists and pathologists knowledge of fetal stomach development allows correct diagnoses and treating of its anomalies, pathologies and varieties. Mechanisms of gastrointestinal tract separate parts growth is less examined (Hussein et al., 1999; Nebot-Cegarra et al., 1999). Disputable attempt in the opinion of many authors is to estimate the moment of final stomach development, characteristic for fetal period. The aim of this research is evaluation of variation in measurable features of the human fetal stomach and based on it, analysis of its growth rate. The description of proportion and shape changeability during prenatal period, as well as course of final features development distinctive for perinatal period. It seems interesting to compare stomach growth analyzed in situ on post-mortem fetuses with results obtained by other authors evaluating this process in sonographic examinations.

\section{MATERIAL AND METHOD}

Research was conducted on 225 post-mortem fetuses (115 male and 110 female fetuses) from collection of Anatomy Faculty Medical Academy in Wroclaw. Age of examined fetuses varied from 12 to 40 week. After opening of abdominal cavity measurements of total stomach length, lengths of greater and lesser curvature and widths of cardia and pylorus were performed. We evaluated the thickness of front wall and bottom of the stomach and its total mass. Using Statistica 8 program package accordance of variables distribution with normal distribution with help of Ko?morogowa-Smirnowa test was performed. Features conditional means, that relates to center of examined age class, which enables material analysis in equal time periods. Analyzed features dynamics of changes was examined by evaluation of relative value increase and by comparing features regression index according to age. Relevance of differences between features increases was estimated using $\mathrm{Z}$ test. Dymorphic differences were evaluated by Morgan test. 
GWORYS, B.; JEKA, S.; BRUKIEWA, R. \& RYMKO, M. Dynamics of stomach growth in the human fetal period - a postmortem study. Int. J. Morphol., 30(2):461-466, 2012.

\section{RESULTS}

Conditional means of examined stomach features estimated on the middle age class considering dimorphic differences were described in Tables I and II.

Evaluation of fetal stomach measurements changeability authorize to state that there is lack of dimorphic differences for every feature in all age classes. This conclusion is confirmed by acquired results assessment using Morgan's test. Due to this fact we resign to split research material considering both genders.

Measurements of stomach length intensive increase - statistically relevant up to 22th week of fetal life (Fig. 1). Growing rate differs. Length of greater curvature is characterized by most growing rate decrease, that between 22 th and 22th week falls from $14 \%$ to $3 \%$. Speed of increase in total stomach length measurements falls in this period only by $3 \%$, and the lesser curvature length is characterized by relative constant growing increase, that oscillates around $7 \%$. There is systematically slowdown of growing process in period from 22th to 28th week, and in 28th week it became statistically irrelevant. Values of total length are irrelevant in 26th week of fetal life. From 28th week increase in stomach lengths is insignificant and not exceeds $2 \%$.

Stomach widths (Fig. 2) represented by cardia and pylorus width show statistically relevant weekly increases till 24th week. Pylorus widths characterize major growing dynamic decrease, that in 26th week comes to $3 \%$, and in 36th week falls practically down to zero. Cardia width increase is more harmonic, growing rate falls weekly $1.5 \%$ until 30th pregnancy week. After 30th week growing of both stomachs widths is lower than $2 \%$ per week and gradually, evenly falls to 0 in last week of pregnancy.

Thickness of bottom stomach wall (Fig. 3) increases in fetal period more intensive than its front wall. Growths till 20th fetal week come to average $17 \%$ per week, when the organ front wall becomes thicker in this period $1 \% /$ week. Relative weekly growths of the bottom wall thickness are

Table I. Mean conditional examined features of male fetuses stomachs.

\begin{tabular}{|c|c|c|c|c|c|c|c|}
\hline \multirow[b]{2}{*}{ Feature } & \multicolumn{7}{|c|}{ A verage fetus age (weeks) $-n=n u m b e r$} \\
\hline & $\begin{array}{c}12-15 \\
(n=13)\end{array}$ & $\begin{array}{c}16-19 \\
(n=17)\end{array}$ & $\begin{array}{c}20-23 \\
(n=20)\end{array}$ & $\begin{array}{c}24-27 \\
(n=19)\end{array}$ & $\begin{array}{c}28-31 \\
(n=18)\end{array}$ & $\begin{array}{c}32-35 \\
(n=16)\end{array}$ & $\begin{array}{r}36-40 \\
(n=12)\end{array}$ \\
\hline Total length & 9.64 & 15.59 & 21.55 & 22.33 & 23.84 & 25.5 & 26.8 \\
\hline Great er curvature length & 17.6 & 39.8 & 47.08 & 54.6 & 58.3 & 61.1 & 62.1 \\
\hline Lesser curvature length & 8 & 11.08 & 15.31 & 18.11 & 19.3 & 20.5 & 21 \\
\hline Width of cardia & 1.7 & 2.49 & 3.1 & 3.64 & 3.8 & 3.92 & 3.94 \\
\hline Width of pylorus & 1.68 & 3.17 & 4.27 & 4.79 & 4.99 & 5.16 & 5.24 \\
\hline Thickness of bottom & 0.23 & 0.8 & 1.3 & 1.5 & 1.59 & 1.66 & 1.73 \\
\hline Thickness of front wall & 1.1 & 1.7 & 1.82 & 1.95 & 2.01 & 2.09 & 2.13 \\
\hline Mass of stomach & 0.67 & 4.08 & 9.39 & 12.21 & 13.9 & 14.2 & 14.6 \\
\hline
\end{tabular}

Table II. Mean conditional examined features of female fetuses stomachs.

\begin{tabular}{|c|c|c|c|c|c|c|c|}
\hline \multirow[b]{2}{*}{ Feature } & \multicolumn{7}{|c|}{ Average fetus age (weeks) $-\mathrm{n}=$ number } \\
\hline & $\begin{array}{l}12-15 \\
(n=12)\end{array}$ & $\begin{array}{c}16-19 \\
(n=16)\end{array}$ & $\begin{array}{c}20-23 \\
(n=19)\end{array}$ & $\begin{array}{c}24-27 \\
(n=20)\end{array}$ & $\begin{array}{c}28-31 \\
(n=18)\end{array}$ & $\begin{array}{c}32-35 \\
(n=16)\end{array}$ & $\begin{array}{l}36-40 \\
(n=9)\end{array}$ \\
\hline Total length & 10.8 & 15.57 & 22.51 & 23.86 & 24.99 & 25.7 & 26.9 \\
\hline Great er curvature length & 21 & 40.3 & 49.2 & 56.1 & 59.3 & 61.8 & 62.8 \\
\hline Lesser curvature length & 7.75 & 11.37 & 15.5 & 18.23 & 19.45 & 20.9 & 21.5 \\
\hline Width of cardia & 2.025 & 2.49 & 3.32 & 3.7 & 3.83 & 3.97 & 3.97 \\
\hline Width of pylorus & 2.47 & 3.46 & 4.53 & 4.85 & 5.11 & 5.23 & 5.26 \\
\hline Thickness of bottom & 0.25 & 0.81 & 1.3 & 1.55 & 1.61 & 1.67 & 1.74 \\
\hline Thickness of front wall & 1.12 & 1.72 & 1.85 & 1.95 & 2.03 & 2.11 & 2.14 \\
\hline Mass of stomach & 1.48 & 4.1 & 10.18 & 13.4 & 14.2 & 14.4 & 14.65 \\
\hline
\end{tabular}


GWORYS, B.; JEKA, S.; BRUKIEWA, R. \& RYMKO, M. Dynamics of stomach growth in the human fetal period - a postmortem study. Int. J. Morphol., 30(2):461-466, 2012.

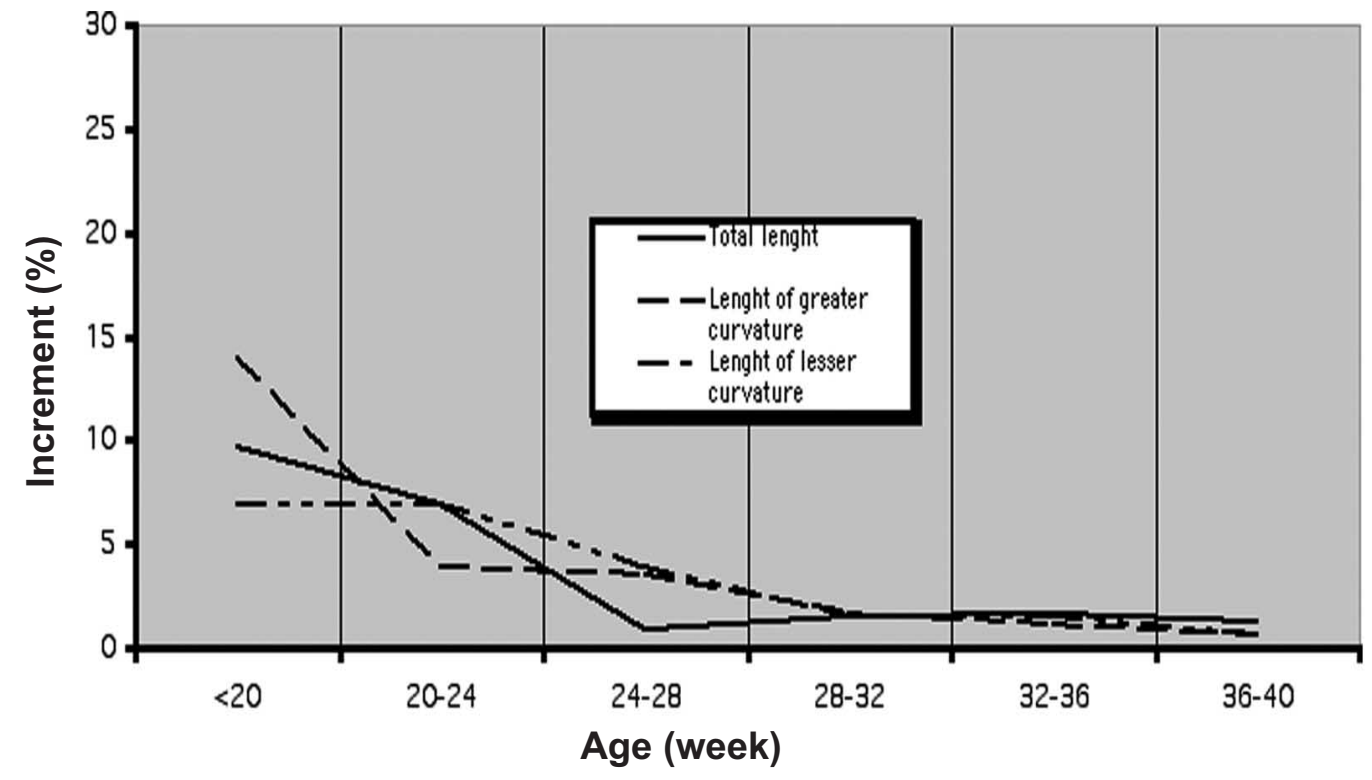

Fig. 1. Dynamics of length stomach dimensions increase and both curvatures lengths.

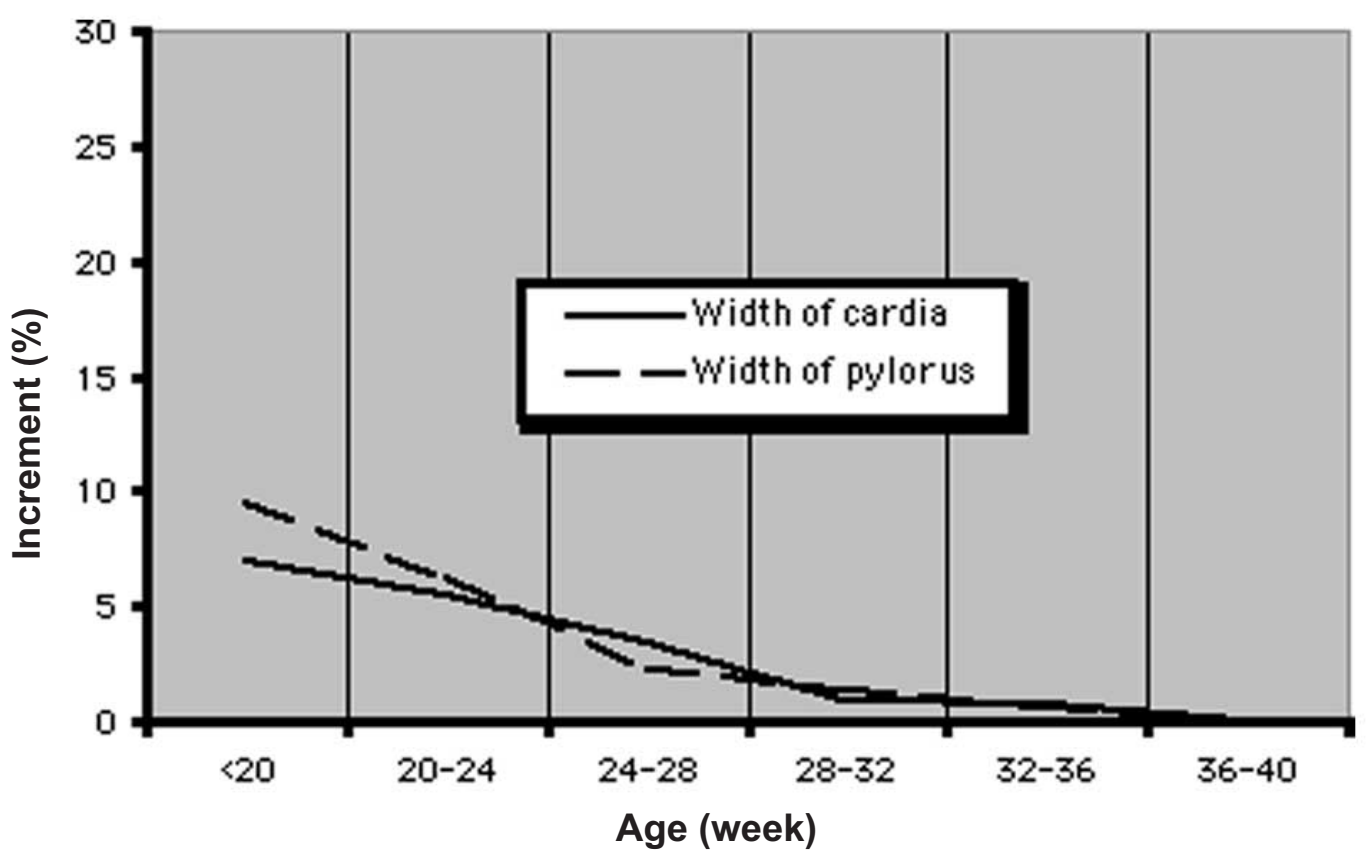

Fig. 2. Dynamics of width stomach dimensions increase: cardia and pylorus width

statistically relevant up to 26th week, and the front wall end its intensive growth in 22th week of pregnancy. From 28th week weekly growths of both discussed features not exceed $1.5 \%$ and lowers in postnatal period.

Stomach mass is characterized by its different from metrical features growth rate (Fig. 4). Weekly growths in up to 20 th week period are very high and exceeds over $17 \%$. In next fetal life weeks decrease successively and in 30 week become statistically irrelevant. This feature growth dynamic decrease to $1 \%$ per week in 34 th week. In following pregnancy weeks $1 \%$ growth remains till the end of fetal period. 
GWORYS, B.; JEKA, S.; BRUKIEWA, R. \& RYMKO, M. Dynamics of stomach growth in the human fetal period - a postmortem study. Int. J. Morphol., 30(2):461-466, 2012.

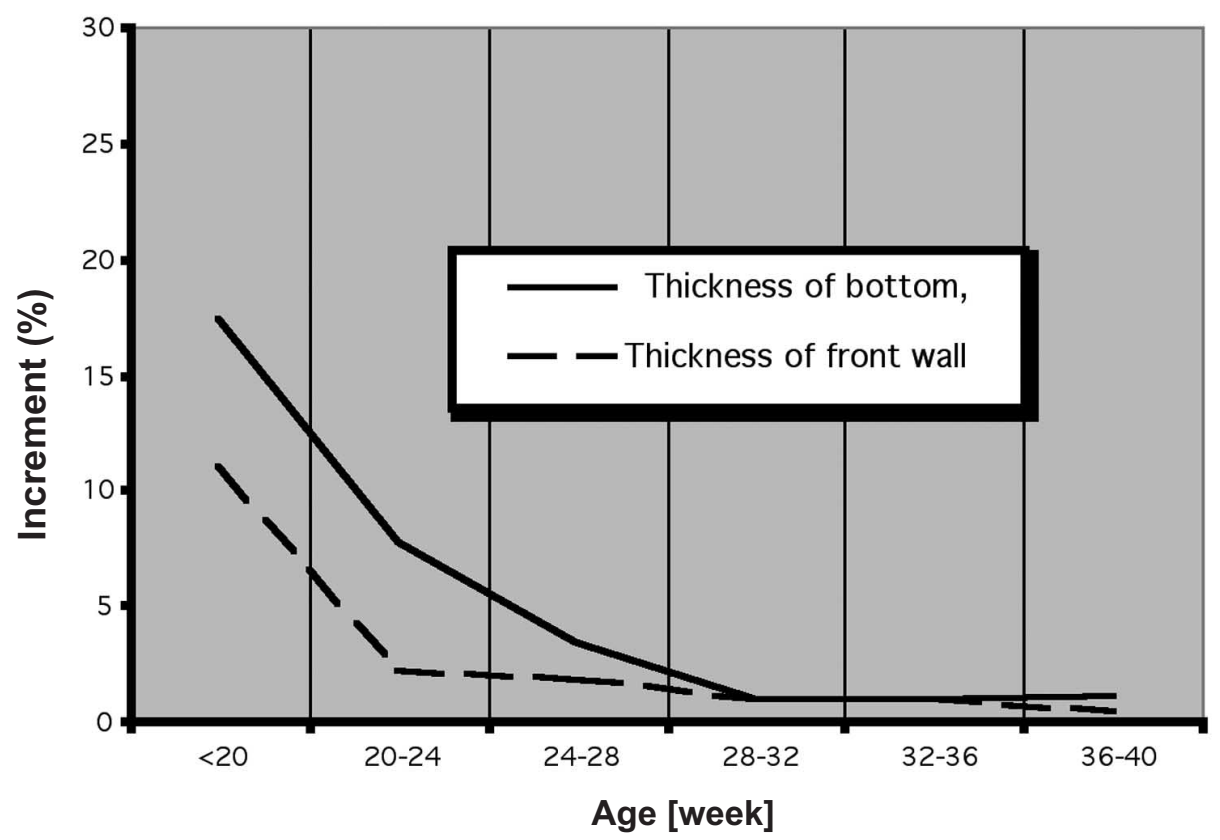

Fig. 3. Dynamics of thickness stomach dimensions increase: bottom and front wall thickness.

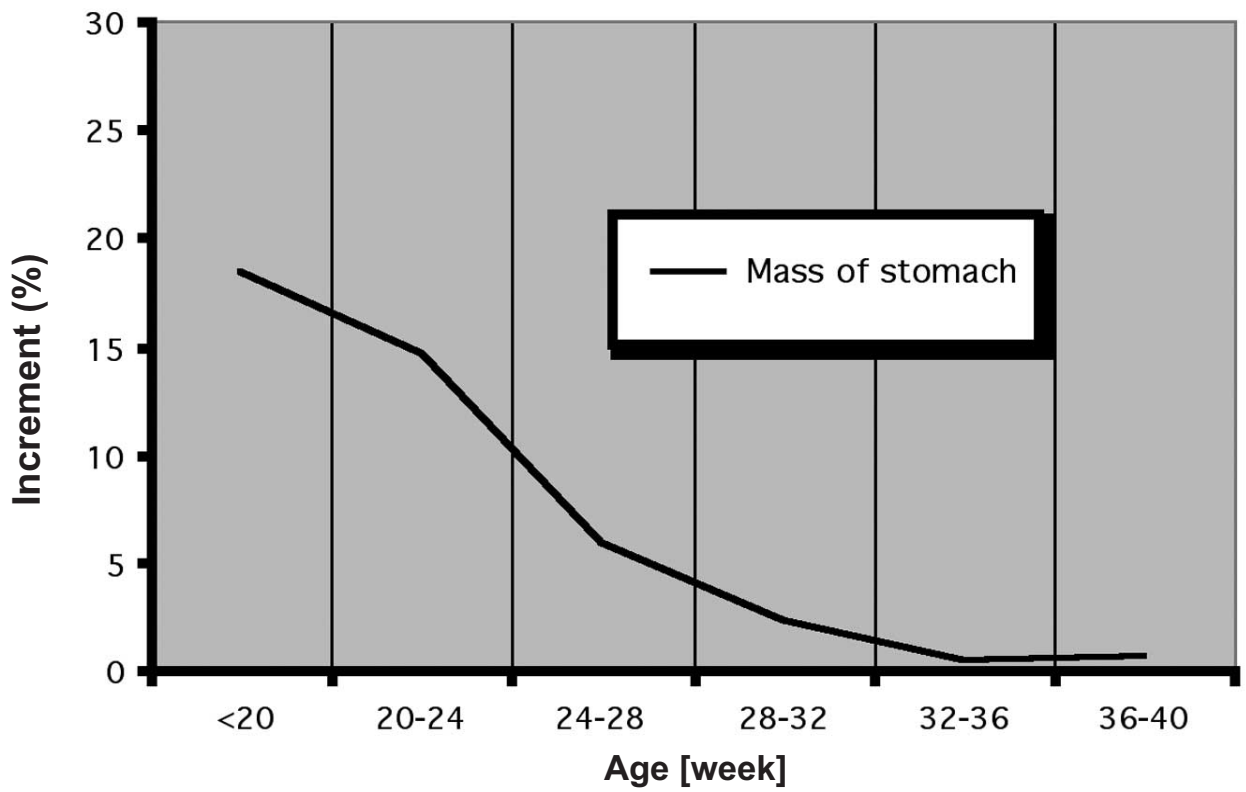

Fig. 4. Dynamics of stomach mass increase.

\section{DISCUSSION}

Evaluation of stomach growth based on weekly relative growths analysis allows objective observation of every simultaneous process. Extremely important issue is possibility of comparison of those processes not taking into consideration the characteristics of examined feature or units used in measurements. Statistical analysis didn't prove 
GWORYS, B.; JEKA, S.; BRUKIEWA, R. \& RYMKO, M. Dynamics of stomach growth in the human fetal period - a postmortem study.

Int. J. Morphol., 30(2):461-466, 2012.

significant dimorphic changes in every parameters measured. Similar results were stated by Cetin et al. Pasquini et al. (2005) on the 2100 fetuses material they have proven, that in $27 \%$ of examined cases there were anomalies in great abdominal blood vessels location. Authors consider this as main reason for versatile growth of abdominal visceral organs, and in part of cases for death in fetal and perinatal period. Hawass et al. (1991) stated that till 22th pregnancy week stomach does not reach its final shape and the greater curvature growth rate is increased in comparison with lesser curvature. Cetin et al. revealed that after second pregnancy trimester stomach length increased more than its width and vertical dimension.

Stomach angle value in fetal period decrease from 1000 to 500. Wide stomach angle was found in first and second trimester mainly, whereas straight angle was more common in third pregnancy trimester. In our research we accomplished more precise results and much better dated. In both genders intensive increase in stomach lengths lasts till 22th fetal week. Stomach length growth lasts also in third trimester but this process is much less intensive than before. Growth of both gastric curvatures is very diverse. Greater curvature develops more intensive growth rate (statistically relevant) till 22th pregnancy week, when weekly growths come to $14 \%$, After this period weekly growths lower gradually till 40 fetal week. Lesser curvature grows more harmonic. Its increase rate in second trimester is relatively constant and comes to 7\%. In third trimester decrease to $2 \%$. Weekly growths of both curvatures take same values around 26th pregnancy week and are very similar to 40th week.

Analysis conducted allows separating four phases of longitudinal stomach measurements development. First statistically relevant intensive growth of every measurements phase lasts till 22th fetal week. It is intensive growth phase. Second phase between 20 and 26 gestational age its versatile growth of both stomach curvatures phase. It can be described as formation of final stomach shape phase. It was observed by Nagata et al. (1994), Yoshizato et al. (1995) and Hata et al. (2010). Their research was conducted on very weak, unrepresentative material (Yoshizato et al., with 11 fetuses, Hata et al. stated that they need to conduct their trial on larger group), or it couldn't precise point in time when those changes occur (Nagata et al., 1994). Phase three between 26 and 30 gestational age of harmonic - almost identically intensive growth of both curvatures, simultaneously minimal increase of total organ length. In this stage increased length of both curvatures by relatively constant values of total organ length cause its location change. It is phase of stomach topography changes. It moves to the left abdominal wall simultaneously lower slightly. Nebot-Cegarra et al. calls this diverse and multifactor rotation in horizontal axis, and causing mezogastrium stretching, thus greatly increase stomach mobility Nagata et al. (1990) date those changes on 26-27 till 32-33 fetal weeks. Last phase lasts from 30 week until childbirth. Harmonic, very weak (weekly growths do not exceed 2\%) stomach growth. It is phase of harmonic, statistically irrelevant growth.

Stomach width dimensions: cardia and pylorus width are characterized by decreased growth in whole examined ontogenesis process. Pylorus grows slightly intensive till 24th pregnancy week, and cardia between 24th and 28th week. Koyuncu et al. confirmed that in pylorus constrictor region growth was more intensive in first and first half of the second trimester than later.

Bottom wall thicknesses increase more intensive (statistically relevant) comparing its front wall thickness. Final thickness bottom wall reaches in 30th week, whereas frontal wall stops its intensive growth in 22th week already. Thus versatile growing rate of bottom stomach wall is always thinner than its front wall.

Stomach mass increase relatively harmonic till 34th pregnancy week. Growth rate decrease successively from $18 \%$ in 20 th week to $1 \%$ in 34th week. After this period there is constant, minimal increase of organ mass.

Analysis performed allows distinguishing four stages of stomach growth in fetal period:

1. Intensive growth phase last till 22th fetal week and is characterized by intensive, statistically relevant increase of its all dimensions. Increase rate of examined features is individually versatile.

2. Formation of final stomach shape between 20th and 26th pregnancy week.. Versatile growth of both stomach curvatures sets final stomach shape. Pylorus and front stomach wall end their intensive, statistically relevant growth.

3. Phase of stomach topography changes between 26th and 30th pregnancy week Increase of both curvatures lengths by relatively constant values of total organ length cause change of its location. It moves to the left abdominal wall simultaneously lowers slightly. Weekly growths of every features examined excluding stomach mass are statistically irrelevant.

4. Phase of harmonic, faint growth (statistically irrelevant) lasts from 30 week until childbirth. In this phase weekly growths of every features examined do not exceed $2 \%$. 
GWORYS, B.; JEKA, S.; BRUKIEWA, R. \& RYMKO, M. Dynamics of stomach growth in the human fetal period - a postmortem study. Int. J. Morphol., 30(2):461-466, 2012.

GWORYS, B.; JEKA, S.; BRUKIEWA, R. \& RYMKO, M. Dinámica de crecimiento deL estómago en el período fetal humano - un estudio post-mortem. Int. J. Morphol., 30(2):461-466, 2012.

RESUMEN: El objetivo fue analizar la tasa de crecimiento del estómago, variabilidad de la proporción y forma durante el período prenatal, así como evaluar las características distintivas del proceso final de diferenciación para el período perinatal. Es interesante comparar el crecimiento del estómago de los fetos analizado in situ en el post-mortem con resultados obtenidos por otros autores tras la evaluación de este proceso en exámenes ecográficos. La investigación fue realizada en 225 fetos post-mortem desde la $12^{\mathrm{a}}$ a la $40^{\mathrm{a}}$ semana de edad fetal. Se determinaron la longitud total del estómago, la longitud de las curvaturas mayor y menor, y los anchos del cardias y píloro. Se evaluó el grosor de la paredes frontal e inferior del estómago y su masa total. El análisis estadístico se realizó mediante el programa Statistica 8. La tasa de crecimiento en las dimensiones de los estómagos post-mortem examinados se estimaron sobre la base de valores medios condicionales caracterizados por el ritmo diverso. Las proporciones de variabilidad en el periodo prenatal resultaron en un crecimiento inarmónico de sus dimensiones. No hubo diferencias dismórficas en proceso de crecimiento fetal del estómago, mientras que en la dinámica de sus proporciones y formas se encuentraron cambios. El período fetal, marca claramente la tendencia a cambios en la forma de órganos acorde con la edad del feto. Basado en el análisis realizado, se distinguen cuatro etapas de crecimiento de estómago en el período fetal: 1 . Fase de crecimiento intensivo hasta finales de la semana 22 del feto. 2 . Formación de la forma del estómago definitiva entre la $20^{\mathrm{a}}$ y $26^{\mathrm{a}}$ semana de gestación. 3. Fase de cambios en la topografía del estómago entre la $26^{\mathrm{a}}$ y $30^{\mathrm{a}}$ semana de gestació. 4. Fase de crecimiento armónico desde la semana 30 hasta el parto.

PALABRAS CLAVE: Estómago; Desarrollo fetal.

\section{REFERENCES}

Cetin, E.; Malas, M. A.; Albay, S. \& Cankara, N. The development of stomach during the fetal period. Surg. Radiol. Anat., 28(5):438-46, 2006

Hata, T.; Tanaka, H.; Noguchi, J.; Inubashiri, E.; Yanagihara, T. \& Kondoh, S. Three-dimensional sonographic volume measurement of the fetal stomach. Ultrasound Med. Biol., 36(11):1808-12, 2010.

Hawass, N. E.; al-Badawi, M. G.; Fatani, J. A.; Meshari, A. A. \& Edrees, Y. B. Morphology and growth of the fetal stomach. Invest. Radiol., 26(11):998-1004, 1991.

Hussein, S. M.; Yoshizato, T.; Fukushima, S.; Koyanagi, T.; Akazawa, K. \& Nakano, H. Rhythmic changes in the stomach movement of the human fetus with congenital duodenal obstruction during the third trimester of pregnancy. Early Hum. Dev., 54(1):1-13, 1999.

Koyuncu, E.; Malas, M. A.; Albay, S.; Cankara, N. \& Karahan, N. The development of fetal pylorus during the fetal period. Surg. Radiol. Anat., 31(5):335-41, 2009.

Macarulla-Sanz, E.; Nebot-Cegarra, J. \& Reina-de la Torre, F. Computer-assisted stereological analysis of gastric volume during the human embryonic period. J. Anat., 188 ( Pt 2):395401, 1996.

Nagata, S.; Koyanagi, T.; Horimoto, N.; Satoh, S. \& Nakano, H. Chronological development of the fetal stomach assessed using real-time ultrasound. Early Hum. Dev., 22(1):15-22, 1990.

Nagata, S.; Koyanagi, T.; Fukushima, S.; Akazawa, K. \& Nakano, $\mathrm{H}$. Change in the three-dimensional shape of the stomach in the developing human fetus. Early Hum. Dev., 37(1):27-38, 1994.

Nebot-Cegarra, J.; Maraculla-Sanz, E. \& Reina-De La Torre, F. Factors involved in the 'rotation' of the human embryonic stomach around its longitudinal axis: computer-assisted morphometric analysis. J. Anat., 194(Pt 1):61-9, 1999.

Pasquini, L.; Tan, T.; Yen Ho, S. \& Gardiner, H. The implications for fetal outcome of an abnormal arrangement of the abdominal vessels. Cardiol. Young, 15(1):35-42, 2005.

Yoshizato, T.; Koyanagi, T.; Nagata, S.; Takashima, T.; Fukushima, S. \& Nakano, H. Three-dimensional ultrasound image of the fetal stomach: congenital duodenal obstruction in utero. Early Hum. Dev., 41(1):39-47, 1995.

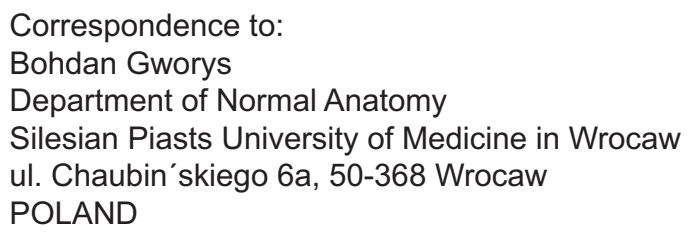

Tel/fax. +48 717841330 ,

Email: bgworys@gmail.com

Received: 23-01-2012

Accepted: 06-03-2012 